\title{
SUSTAINABILE ORGANISATIONS FOR GREEN BUILDING DESIGN
}

\author{
Ayushi Jain $^{1 *}$ Ar. Prashant Chauhan ${ }^{2}$ \\ ${ }^{1} P G$ Student, Sustainable design, Vivekananda Global University, Jaipur, Rajasthan (India) \\ ${ }^{2}$ Assistant Professor, Vivekananda Global University, Jaipur, Rajasthan (India)
}

Article DOI: https://doi.org/10.36713/epra8011

DOI No: 10.36713/epra8011

\begin{abstract}
Many of today's commercial industries are realizing the negative impact they have on the Environment and taking steps to become more sustainable in hopes of lessening that impact. The hotel industry is one of those industries. Hotel owners and guests are expressing their concern for the environment, and both are playing a role in making the hotel industry more sustainable. With the help of government organizations, better technology, and green education, the idea of environmentally friendly hotels is not just an idea; it is becoming the norm.
\end{abstract}

\section{INTRODUCTION}

One of the leading contributors to the depleting of our natural resources is the hospitality industry; sustainability, reducing the carbon footprint, and lowering operating costs have all become important focuses of the industry. Energy concern is not a new concept for the industry; the energy crisis of 1973-74 caused concern about utility costs and energy supply, which prompted hoteliers to focus on energy conservation strategies. Other time points related to the idea of sustainability include the 1990s, which brought about the first hospitality specific environmental certification programs; the LEED green building program came into the forefront during the 2000s; and the financial crisis of 2008-2009 prompted hoteliers to reevaluate their cost control measures and reduce utility costs. The challenge with the hotel industry is that it operates 24 hours a day, 7 days a week, 365 days a year, with guests expecting certain luxuries, such as restaurants, fitness centers, and spas. This poses the problem; how can the industry be sustainable but still maintain the level of luxury that guests expect when staying at a hotel?

Sustainable development was first defined in 1987 in a report written during the Brundlt and Commission of the United Nations as "development that meets the needs of the present without compromising the ability of future generations to meet their own need" (Winchip, 2007). In other words, a sustainable development should do its best to create less of an impact on the environment as well as sustain natural resources. From sustainable development comes the idea of sustainable design. In her book Sustainable Design for Interior Environments, Susan M. Win chip defines sustainable design as "design that reflects respectful interaction between people and the earth by conserving resources for current and future generations," and the principles that define it serve as the foundation for sustainable design.

The purpose of this report is to provide a strong argument that the hotel industry is a good candidate for becoming more sustainable and strategies it can take to reach that goal. This report will look at three of the largest strains the hotel industry places on the environment: the consumption of energy and water and the production of wastes. More importantly, it will look at what sustainable strategies can be used to reduce the environmental strain through energy efficiency, water conservation, recycling, and "green "design. A number of case studies and benefits will be discussed to help strengthen the argument that the hotel industry is capable of becoming sustainable. 


\section{SUSTINABLE ORGANISATIONS}

In the United States, the hotel industry represents more than five billion square feet of space and pays close to $\$ 4$ billion in annual energy use (LEED). According to an article on Eco Traveler's website, the hotel industry uses 84.7 billion kilowatts of energy, 219 billion gallons of water and creates 1.9 billion pounds of trash per year. (Figure 1)

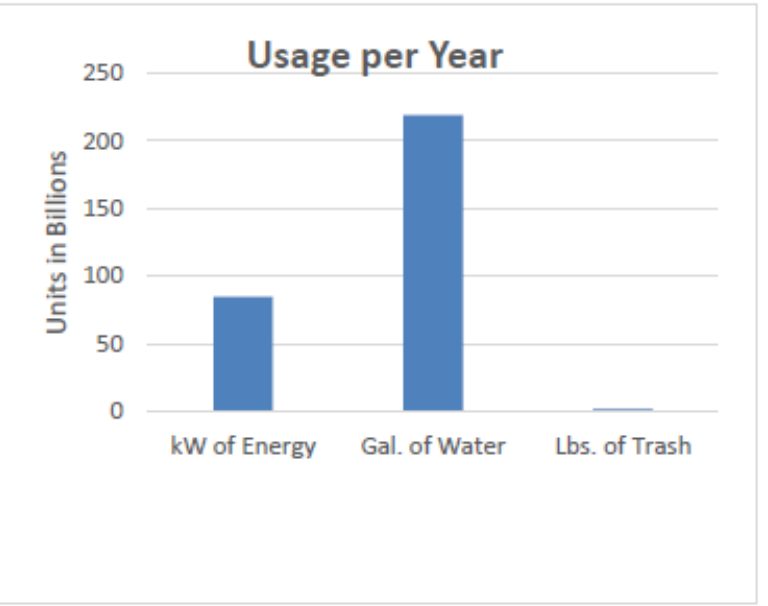

Figure 1Yearly energy, water, and waste consumption

An average energy cost of $\$ 2,196$ is spent per guestroom (Energy star, 2008). These staggering numbers are a good representation of why the hotel industry is a perfect candidate for sustainability. The Environmental Protection Agency (EPA) reports that the hotel industry could save $\$ 745$ million annually just by reducing energy use by $10 \%$ (Hetter, 2013). The large consumption of energy and natural resources is part of the reason why a number of organizations were created to address sustainability specifically for the hotel industry. These organizations have created guidelines for the industry to follow in order to become an eco-friendlier, energy-efficient development and award certification to hotels that meet those guidelines. An online article by Eco Green Hotel states that according to the World Tourism Organization, ecotourism, a form of environmental tourism, is the "fastest growing market in the tourism industry, growing at a rate of $5 \%$ worldwide and representing over $11 \%$ of all consumer spending" (Parisi \& Burger, 2012). Throughout the last few decades a number of certifications have become available, many of them with different guidelines making it very confusing for hoteliers and guests to determine which certification works for them. The following section addresses these organizations and their guidelines.

\section{LEED}

The United States Green Building Council (USGBC) developed LEED, Leadership in Energy and Environmental Design, in 2000; it provides a rating system for the design, construction, and operation of a green building. The system was created to define what it means to be a "green" building, recognize environmental leadership in the building industry, promote green competition, and raise consumer awareness of the benefits of a green building. To become LEED-certified means that a third party has verified that a building was "designed and built using strategies aimed at achieving high performance in key areas of human and environmental health: sustainable site development, water savings, energy efficiency, materials selection and indoor environmental quality" (LEED). Professionals in the building industry developed a rating system organized into five credit categories: sustainable sites, water efficiency, energy and atmosphere, materials and resources, and indoor environmental quality. In order to become LEEDcertified, a building must acquire a certain number of points under each category. Once these credits are obtained, there are four different LEED certification levels: certified the lowest number of points; silver; gold; and platinum, the highest number of points.

Some of the advantages of becoming a LEEDcertified hotel include lower operating costs, increased property value, and a healthier and safer environment for its occupants. Lower operating costs result in lower utility bills and maintenance costs, LEED buildings have been shown to have a higher market value for new and existing construction, and improved indoor air quality provides and healthier work environment for its employees. As of 2011; 17 hotels were LEED certified, 27 were LEED silver, 33 were LEED gold, and 2 were LEED platinum (Figure 2). In 2011, the number of LEED certified hotels more than doubled in one year.

To become LEED certified is an important accomplishment in the industry; not only to other competitors, but to guests and the media as well. LEED is becoming a common place reference for those that are environmentally conscious; being awarded LEED certification can attract the "green" traveller, defined as a person who is environmentally conscious and seeks sustainable accommodations when travelling. 


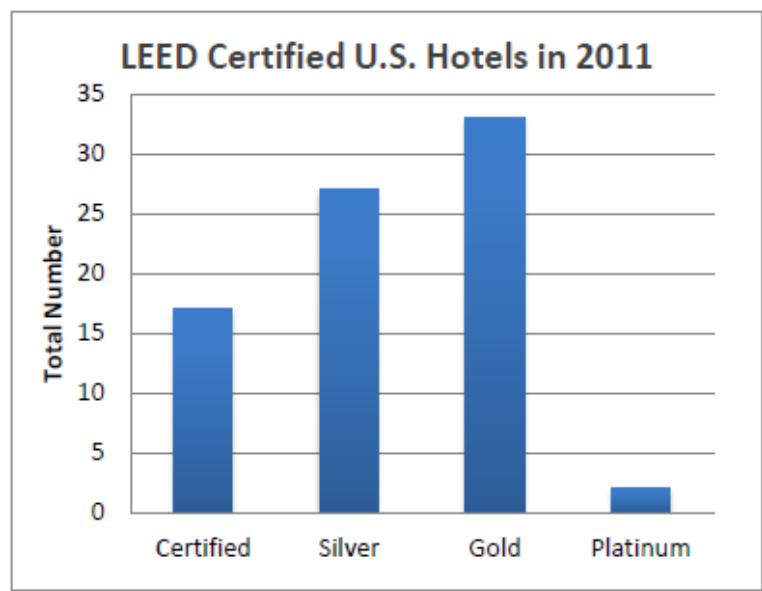

Figure 2 Interlocking Carpet Tiles

\section{USGBC}

As mentioned above the USGBC is responsible for developing the LEED system. The USGBC was founded to promote environmentally responsible buildings, as stated on their website the organization hopes to enable "an environmentally and socially responsible, healthy, and prosperous environment that improves the quality of life." The organization provides guides that give examples of green strategies for different types of LEED-certified buildings; from residential to hospitality. The guide for hotels is broken down into the six credit categories of LEED and gives examples of how LEED certified hotels have fulfilled the requirements.

\footnotetext{
ASHRAE

Another organization that sets standards for energy efficient design is the American Society of Heating, Refrigerating, \& Air-conditioning Engineers (ASHRAE), founded in1894; today the organization focuses on energy efficiency, building systems, indoor air quality, and sustainability. A strategic plan was created to make the building industry more sustainable that includes four directions the organization will take to make this happen. The first direction is that "ASHRAE will be a leader in advancing sustainable design, construction, and operations for new and existing built environments" (ASHRAE, 2011). Strategies to achieve that include promoting the use of life-cycle analysis, influence research, and education for "systems and equipment to be used in high-performing buildings." Another strategy is to lead the development of integrated design that includes energy efficiency, water conservation, and indoor environmental quality. The second direction is for ASHRAE to become "a world class provider of education and certification programs," by providing on demand education, partnering with other organizations around the world and encouraging the use of ASHRAE documents on
}

sustainable building at universities and technical schools. The third direction is to "position itself as an essential resource for optimizing the performance of building and energy systems throughout their life cycle." They hope to accomplish this through aggressive marketing, conducting market research and establishing and maintaining relationships with key government agencies. The final direction ASHRAE hopes to take is to become a "global leader in the building and energy system community." By providing staff support outside of North America and conducting global meetings and conferences, more countries will be educated in energy systems for an entire sustainable building.

ASHRAE publishes design guides for all of the building industry on how to create energy efficient designs. For hotels, it looks at how to achieve $30 \%$ energy savings, the guide covers hotels that have up to 80 rooms, but the same strategies could be applied to a much larger luxury hotel. ASHRAE 189.1 deals specifically with the design of high performance green buildings, providing requirements for "the sitting, design, construction, and plan for operation of high performance green buildings to: balance environmental responsibility, resource efficiency, occupant comfort and wellbeing, and community sensitivity" (Standard, 2009).Much like LEED, ASHRAE 189.1 focuses on water use efficiency, indoor air quality, energy efficiency and the building's impact on the environment.

\section{GREEN HOTEL ASSOCIATION}

Hotel sustainability has come to the forefront of the hospitality industry with the help of numerous organizations developed to promote sustainability. Perhaps the most notable organization is the "Green" Hotel Association or GHA. Founded in 1993 by Patricia Griffin; their mission statement is to "promote and support the "greening" efforts of the lodging industry by researching and sharing information primarily on water and energy conservation and waste reduction" (Wilfong, 2009). Once hoteliers become a member, they are given a150-plus-page document called Membership Conservation Guidelines \& Ideas that has tips for becoming a "greener" hotel and lists of "green" products hotels can use. As of 2009, the association had more than 500 members and it is the "longeststanding, most experienced green hotel association in the world" (Bohi, 2009). The GHA magazine IMPACT was launched to expand the message of the benefits of going green. Issues of the magazine contain valuable information on new "green" products available for hoteliers, examples of sustainable hotels in the industry, energy efficient strategies, and ways to teach staff about the importance of sustainability. 


\section{OTHER ORGANIZATIONS}

Organizations such as LEED and USGBC are better suited for new builds or hotels that are undergoing renovations, but there are several other programs suited for already existing hotels. One of these certification programs is Green Key Global, a Canadian certification program that in recent years has made its way to the United States. The basis of this certification is a 140-question online audit; hotels are awarded based on the results of these audits and given a rating of one to five Green Keys. The audit looks at nine areas of sustainable hotel operations: energy and water conservation, solid and hazardous waste management, indoor air quality, community outreach, building infrastructure, environmental management, and land use. Green Globe International is the standard for green hotels worldwide, certified hotels have to be re-certified on an annual basis and the program often updates certification requirements. Because many hotels cannot afford to completely rebuild, the intention behind the organization is to identify practices and habits that hotels can adopt to create less of an impact on the environment.

The EPA created the Energy Star program about ten years ago to reduce energy consumption and greenhouse gas emissions. The benchmarking system, Portfolio Manager, allows managers to enter their energy usage to measure the energy performance of the building; this gives them a concrete idea of how well they are saving energy. Energy Star has proven to be a successful program and buildings that have earned the Energy Star label use almost $40 \%$ less energy and emit 35\% less carbon.

Green Seal is a science based environmental certification; to obtain a certification a hotel must go through an initial evaluation, an on-site audit, and annual monitoring to ensure compliance. To qualify for Green Seal certification, a hotel must demonstrate recycling and waste minimization, energy efficiency, management of wastewater, fresh water resources, and hazardous substances, and environmentally sensitive purchasing. An important aspect of this program is making sure the hotels that are certified are doing what they say they are doing and why annual audits are implemented.

In 1998, the Audubon Green Leaf Eco-Rating Program was introduced "to meet the lodging industry's desire to provide quality guest services while minimizing its impact on the environment" (Parisi \& Burger, 2012). Hotels are awarded one to five Green Leaves based on four practices: saving energy, reducing waste, conserving water and resources, and preventing pollution. The program is unique in that it provides a "checklist for evaluating environmental performance," by providing environmental education and hands-on staff assistance, this idea will be addressed later on in this paper, a program can only be successful When managers and employees are educated about the environmental practices.

Eco Rooms \& Eco Suites has not only developed an online directory for guests to find the most environmentally responsible hotels but has begun to push for a more sustainable hospitality industry. The organization has formed a set of Eco Criteria for hotels to follow with two tiers of green designations: the first is the "approved" status and is based on the satisfactory completion of an application, to become "certified," the second tier, the hotel must undergo an on-site audit. Eco Rooms \& Eco Suites is the only program that makes it mandatory for a hotel to complete all of their eight criteria at $100 \%$, making them the most stringent certification program in the industry; as of 2012 there were about 12 hotels that had received certification. Some of their criteria include energy-efficient lighting in every applicable area; a linen and towel reuse program, high efficiency plumbing, and recycling in guest rooms.

To date, there are many sustainable hotel developments that have followed the guidelines of the above-mentioned organizations and as a result are now much more energy efficient and have created less of an impact on the environment. The following section addresses the ways in which hotels can follow these guidelines and what sort of techniques and products are available to them today.

\section{CONCLUSION}

All the above information in this report leads to a question many in the hotel industry are asking themselves, besides helping the environment what other benefits are there to becoming sustainable? Besides the obvious; sustaining natural resources, creating a smaller carbon footprint, and creating a healthier environment for guests and staff; there are other benefits to going "green."

There is a competitive advantage. Due to the rising costs of energy and the growing concern for the environment, there may one day be a requirement for the hospitality industry to be more sustainable. If this is the case, those hotels that took the "green" initiative early on will have an advantage over those hotels that have not.

There are a number of options the hotel industry can take to become more sustainable; from simple measures like implementing a towel and linen reuse program to using sustainable materials and strategies from the ground up in a new build. There has been enough research done to show that the money a hotel can save is worth the initial investment.

A hotel cannot just implement sustainable features with a guarantee that it will be successful, 
education is an important part of the process, and without it the program will not work. This is perhaps the biggest hurdle that the hospitality industry faces. There are a number of misconceptions and educating managers, staff, and guests on the importance of a green redevelopment can make for a more successful program.

\section{INDEX TO ABBREVIATIONS}

AH\&LA-American Hotel \& Lodging Association

ASHRAE- American Society of Heating, Refrigerating, and Air-Conditioning BMS-building management system

CFL-compact fluorescent lamp

EPA-Environmental Protection Agency

GHA-Green Hotel Association

HVAC-heating, ventilation, and air conditioning

IAQ-indoor air quality

IEQ-indoor environmental quality

LEED-Leadership in Energy and Environmental

Design

USGBC-US Green Buildings Council

VOC-volatile organic compounds

\section{REFERENCES}

1. Alexander, S. (2002, September). Green hotels: Opportunities and resources for success. Retrieved from http://www.zerowaste.org

2. American Hotel \& Lodging Association, (n.d.). AH\&LA green guidelines. Retrieved from website: http://www. ahla.com/green.aspx

3. American Society of Heating, Refrigeration, \& AirConditioning Engineers, (2011).ASHRAE strategic plan. Retrieved from website: http://www.ashrae.org

4. Residential buildings. Retrieved from website: http://www.usgbc.org

Bauld, S., \& McGuiness, K. (2007, October). LEEDing into the future. Summit, 10(6),12-13.

5. Bohdanowicz, P. (2005). European hoteliers' environmental attitudes: Greening the business.Cornell Hospitality and Restaurant Administration Quarterly, 46(2), 188-204. doi:10.1177/0010880404273891

6. Bohi, H. (2009). Green focus: Unraveling the hype. Impact. Retrieved from http://greenhotels.com/pdf/09Sepimpact.pdf.

7. Bonda, P., \& Sosnowchik, K. (2007). Sustainable commercial interiors. Hoboken, NJ: JohnWiley \& Sons. 